\title{
THE TEACHINGS TO REACH LIFE SAFETY AND CHARACTER VALUES IN SERAT GEMBRING BARING
}

\author{
Baktya Tri Setiono dan Endang Nurhayati \\ Universitas Negeri Yogyakarta \\ Email: baktya.ts@gmail.com
}

\begin{abstract}
This research aims to (1) inventory and describe the manuscript of Serat Gembring Baring; (2) display and describe the teachings to reach life safety in the manuscript; and (3) explain the character values in the manuscript. The data are all text or lyrics song in the manuscript. The type of this research was descriptive research with a content analysis method. The process of collecting the data is done by reading technique, taking note and also selecting or reducing the data. The data were analysed descriptively. The validity of the data was gained through semantic validity. Intrarater and interrater reliabity was used to gain the reliability of the data. From the results of the analysis, there are 11 text of Serat Gembring Baring and the manuscript used in this research is still well. There were 6 things that must be done to achieve safety (1) must have knowledge; (2) must learn about theology (Islam) and science of Java; (3) do the goodness; (4) stay away from the bad things; (5) always pray; and (6) have faith. There are 10 characters values in Serat Gembring Baring still related to present life, including religiousity, honesty, discipline, preserance, democracy, curiousity, respect, friendliness, sociability, and responsibility.
\end{abstract}

Keywords: safety, character value, serat gembring baring

\section{AJARAN UNTUK MENCAPAI KESELAMATAN HIDUP DAN NILAI KARAKTER DALAM SERAT GEMBRING BARING}

\begin{abstract}
Abstrak: Penelitian ini bertujuan untuk (1) menginventarisasi dan mendeskripsikan naskah Serat Gembring Baring; (2) menyajikan dan mendeskripsikan ajaran untuk mencapai keselamatan hidup dalam naskah; dan (3) menjelaskan nilai karakter dalam naskah. Data semua teks atau lirik lagu dalam naskah. Jenis penelitian ini adalah penelitian deskriptif dengan metode analisis isi. Proses pengumpulan data dilakukan dengan teknik membaca, mencatat, dan juga memilih atau mengurangi data. Data dianalisis secara deskriptif. Validitas data diperoleh melalui validitas semantik. Reliabilitas intrarater dan interrater digunakan untuk mendapatkan keandalan data. Dari hasil analisis, ada 11 teks Serat Gembring Baring dan naskah yang digunakan dalam penelitian ini masih baik. Ada 6 hal yang harus dilakukan untuk mencapai keselamatan: (1) harus memiliki pengetahuan; (2) harus belajar tentang teologi (Islam) dan sains Jawa; (3) melakukan kebaikan; (4) menjauh dari hal-hal buruk; (5) selalu berdoa; dan (6) beriman. Ada 10 nilai karakter dalam Serat Gembring Baring yang masih terkait dengan kehidupan saat ini, termasuk agama, kejujuran, disiplin, preseransi, demokrasi, rasa ingin tahu, rasa hormat, keramahan, keramahan, dan tanggung jawab.
\end{abstract}

Kata Kunci: keselamatan, nilai karakter, serat gembring baring

\section{INTRODUCTION}

Java script is a type of Javanese literature that contains a variety of important events, stories of heroism, the live community, and so on. In addition, in some of the Java script is also explained about the life of the State, legal, customs, religious life, as well as education (Darusuprapta, 1985:
133). One of the Java scripts that contain various aspects of life that are sublime as education and religion is Serat Gembring Baring.

Serat Gembring Baring is a Javanese literature composed by R.T Prawiradireja in Madiun. Serat Gembring Baring contains teaching education about moral and reli- 
gious as the ones in the instructions and of society. In its content, Serat Gembring Baring tells things to do someone in life in order to gain glory and safety both in the world and in the hereafter. The contents or the teachings in Serat Gembring Baring are universal so that it can be applied over time.

In the text of Serat Gembring Baring told to grab the survival both in the world and in the hereafter, there are a few things to do. This is in accordance with the opinion of Dhavamony (1995:316) stating that survived is the situation where someone away from a variety of things that can be made wretched. Therefore, to achieve salvation in life must be away from things that are not good, as the deed was bad, lust and other various things that can be a source of woe. Therefore, teaching/education in Serat Gembring Baring, this could be the the instructions or guidelines in your everyday life. With such teachings, someone will understand about different things both good and bad, as well as knowing what to do and what should be avoided.

Education cannot be separated from the values, especially the quality of intelligence, scientific values, moral values, and religious values. According to Webster's (Muhaimin, 2006:148), "A value, says is a participle, standart quality regarde as worth or desirable", or value is a quality standard. The value is the abstract concepts of someone on the basis of matters relating to the good, bad, right and wrong. There are some value realizations in the life of the community such as the value of beauty, the value of integrity, value decency, value education, and so on.

The teaching values in Serat Gembring Baring are very important to add the knowledge to society so the value is not lost. The values can also be applied to students at school as well as the youth. It became one of the backgrounds why Serat Gembring Baring needs to be examined to clarify information as well as the teachings contained therein for the community.

One way to examine the old Javanese script is using philology which philology researching about the relationship of the lifeof the present with the past lives through words and text as the social window, religion, history, economics, politics, and the other (Olivele, 2012:23). However, this study only focused on analysis of the contents of the text because Serat Gembring Baring which became the object of research has been created instead wrote in previous research.

Teaching is an activity which contains various things to create the behavior and mindset of the person. The value is the abstract concepts of someone on the basis of matters relating to the good, bad, right and wrong. The character is the universal values the behavior of someone who contains all actions in life, connected with God, self, others, or the environment in the form of ideas, behaviors, feelings, words, and actions based on religious norms, laws, manners, customs, and culture (Suyadi, 2013:5). Therefore, education always related to value, and value is always associated with the character.

Education taught many things related to the value of the character. Character value is the value of a life that is needed and very important, so that one becomes a personal or individual that fits the personality of nation and state. Someone is expected to have a good personality or character, being formed from the words, actions and behavior, thought, attitude, and the results of his work through education and the character value.

Serat Gembring Baring contains the teachings to achieve life safety. The teach- 
ing safety can not be separated from values which it contained the character values that are useful for life. Therefore, teaching safety and value of the characters contained Serat Gembring Baring must be examined and elaborated so that it could be useful for the community.

From the explanation above, it can be noted that assessment against Serat Gembring Baring concerning the safety of life and the value of the characters is needed. The study was conducted to obtain information and great value that can be applied in the life of society at this time.

\section{METHOD}

This research is descriptive qualitative by using content analysis approach. Content analysis was used to get a description of the communication in the form of signs that can be taken documentation. The contents of communications transmitted through the mass media or other sources with objective, systematic, and relevant can be understood by using content analysis method (Suprayogo, 2001:6).

The data source is the text of Serat Gembring Baring, the library collection of Balai Bahasa Yogyakarta that is contained in Serat Panacitra manuscripts number 95 or R00171. It was the result of my research before, Baktya Tri Setiono in 2014 with the title "Kajian Filologi Saha Piwulang Moral Wonten Ing Serat Gembring Baring", while the data is the text or the lyric of the song in Serat Gembring Baring.

The step of collecting data is manuscriptinventory, manuscript description, and content analysis. An inventory and description of the script is used to know the whereabouts and situation of the original data source. It was used to examine the data. There re three ways to analyze the data, they are reading, taking notes, and analyzing the data based on what will be examined (Sudaryanto, 1993:133).

The research instruments are in the form of data card and interview guidelines. The data card is used to record all associated with data resource, while the interview guideline is used to validates the data already found by the experts. The data analysis is descriptive analysis in accordance with the concept of reaching the safety of life and the value of the character. There are four steps: (1) data reduction; (2) classifycation of data; (3) display data); and (4) interpretations. The validity is semantics validity, which is intrepret the data in accordance with the context. Then reliabilities used are intraratter reliability and interratter reliability.

\section{RESULT AND DISCUSSION \\ Result \\ Inventory and Manuscript Description}

An inventory of the manuscript is done by catalogue study as well as sees the firsthand place of Serat Gembring Baring text. From the results of an inventory, it can be known that there are 11 Serat Gembring Baring texts. Seven texts are stored in the Yogyakarta region, two texts in Surakarta, one text is stored in University of Indonesia, and one text stored in the library of University of Leiden, Netherlands.

The description of the manuscript is Serat Panacitra description that containied in Serat Gembring Baring the colletion of Balai Budaya Yogyakarta library. The manuscript has colletion number in catalogue that is 95/R00171. The manuscript was copied in 1933 by Den Mas Suryagrahana, whereas the author of Serat Gembring Baring is Raden Rongga Prawiradireja. It is still in good condition with a full page letter and written using Java letter. It consists of 4 song, they are Sinom consists of 
29 couplets, Dhandhanggula consist of 31 couplets, Pangkur consists of 43 couplets, and Durma consists of 97 couplets.

\section{The Teachings to Reach Life Safety}

\section{- Must have Knowledge}

Serat Gembring Baring contains about how human beings gain life safety, be it the salvation of the world as well as salvation in the hereafter. Human must have knowledge in order to distinguish which one is good and which is bad. With abstinence from bad deeds, then mankind will survive the dangers and will receive a blessing. Knowledge as a means to avoid bad deeds is described in the piece of Serat Gembring Baring below.

utamané srawungan lan anglir / lan wong ingkang samyå ulah nalar / lan wong mangulah ngèlmuné / wus pasthi manggih untung / nora tunå sabarang budi /

(SGB/Dha/p24/g1-5)

Keutamaan bergaul dan membaur dengan manusia yang menggunakan akal dan ilmunya sudah pasti mendapatkan keuntungan, tidak rugi akan hal baik.

/ rumêkså nalar mulyå / êndi liré ingkang anjidhari laku / angangsarakên cilåkå / ambubrah ing nalar bêcik //

(SGB/Pang/p6/g4-7)

Jagalah akal yang baik yang mana untuk membatasi perbuatan yang menyengsarakan, mencelakakan, dan merusak akal baik.

From the text above, it can be known that people who have knowledge surely will keep the sense of mind, and get advantages. The advantages are keeping though, eating good and will not have enemies, it will not be disturbed by others, so his life will be peaceful.

\section{- Must Learn about Theology (Islam) and Science of Java}

To reach the life safety, human should learn the Arabic and also Java knowledge.
Both of them are major knowledge. They can bring salvation in the world (knowledge of Java) or salvation in the hereafter (Arabic knowledge). It is stated in section of Serat Gembring Baring below.

iku mungguh praboté wong urip / mångkå sampun samyå kêlampahan / salah siji kawignyané / bab tåtå kramanipun / angawruhi ing sastrå Jawi / miwah aksårå Arab / bangbuné krahayun / salah siji wong agêsang / åjå lumuh ing sastrå Arab myang Jawi / sokur wignyå sêdåyå // (SGB/Dha/p30/g1-10)

Ini merupakan salah satu kebutuhan hidup, padahal sudah terlaksana salah satunya yaitu tata krama. Pelajarilah Sastra Jawa dan Satra Arab yang berisi tentang keselamatan. Jangan sampai sungkan untuk belajar Sastra Arab dan Sastra Jawa, syukur bisa pintar keduanya.

From the text above it can be known that knowledge is a necessity in life. Both of them contains about salvation, people should learn Arabic as well as Java knowledge.

\section{- Do the Goodness}

In addition to learning science, during life people should always do good deeds and stay away from evil deeds. A good deeds will bring happiness, while deeds will harm humans themselves and others. An example about doing goodness in Serat Gembring Baring is explained below.

/ yèn sirå tan suminggah / anglakoni nalar bêcik / åjå kèri lan anak putuné kumprå //

(SGB/Sin/p22/g7-9)

Apabila manusia tidak berbuat baik, kelak keturunannya akan menjadi sampah.

From the section of Serat Gembrig Baring above, it can be known if the people do not a good things, their generation will be useless in the future. Good deeds should be done because that will get in return for them who did and also for their genera- 
tions. Therefore, we should do the goodness in order to get life salvation.

\section{- Stay Away from the Bad Things}

Human beings who want to reach the perfection of life both in the world and in the hereafter should stay away from the bad things. The section of the Serat Gembring Baring which explains about avoiding the bad things as below:

lamun sirå mrih. rjaning dhiri / ing ngêdohnå barang tindak nisthå / kang tan patut lan ing akèh / miwah walêring guru / Gusti lawan båpå myang kaki / babu myang sanak tuwå /

(SGB/Dha/p7/g1-6)

Apabila manusia ingin selamat, jauhi perbuatan nista, perilaku yang tidak pantas dan perbanyak menurut pada larangan guru, Gusti, bapak, simbah, ibu dan saudara yang lebih tua

From the text above, it can be known that we can get a life salvation if we stay away from the bad things. It is a must, so we can away from disaster. Therefore, we have to keeping away from the bad things due to get life salvation.

\section{- Always Pray}

Pray is an activity that will bring closer a man with the God. Pray to God has become a duty of human beings, because God is the essence of creating and mastering life and determine whether a survivor or a being. The section of Serat Gembring Baring that explains about praying as below.

/ lamun têmên kalêksanan ing pamuji / mulyané kang sarirå //

(SGB/Dha/p6/g9-10)

Apabila sungguh-sungguh berdoa, maka akan menjadi manusia yang mulia.

From the text above, it can be known that man who fervently prays to his God, they will become a good man. They surely will always get the grace of the God and will be removed from the wretched or danger.

\section{- Have Faith}

Faith according to Poerwadarminta (1939:171) is a belief associated with religion. Faith can also mean a recall. With faith, then the people will always remember to God, as exemplified in Serat Gembring Baring below.

// ingran iman éling marang ing pangéran / éling sarirå dhiri / éling ing pratingkah / éling arjå myang rusak / éling iku dudu lali / sarat ginulang / ngèstokên nalar bêcik // (SGB/Dur/p29/g1-7)

Yang disebut iman itu ingat (percaya) terhadap Tuhan, ingat terhadap diri sendiri, ingat terhadap tingkah laku, ingat terhadap keselamatan dan kerusakan. Ingat itu tidak lupa sarat belajar supaya akal menjadi baik

From the above texts, it can be known that with faith, the people will remember to God, remember their self, and remember about salvation. With faith, then people will always keep their attitude from woe. This is because they believe that God will see everthing we have done, therefore if humans do not keep their deeds will surely got a reply from God.

\section{Character Value in Serat Gembring Baring \\ - Religious}

Religious is a character value in relation with the God, which indicates that the thoughts, words, and actions of a person always based on the values of the Godhead and his religious teachings (Mustari, 2011: 1). Religious makes a human have a faith and strong belief to their God. Belief to the God will manifest the human being who is obedient and behave accordingly to what is embraced by religion and not do anything 
that is prohibited by the religion. The value of religious character is in the text of Serat Gembring Baring below.

// pan wus kocap taati Ngullahi / kaping dwi wa atingulrasulla / ping tri wa ulul amriné / wêdiå mring Hyang Agung / lan wêdiå mring rasul sami / lan pådhå mituhuwå / paréntahing ratu / Allåh Muhammad lan råjå /

(SGB/Dha/p19/g1-8)

Sudah diucapkan yang pertama taat kepada Ngullahi, yang kedua taat kepada rasulla, dan yang ketiga taat kepada para ulul amri. Takutlah kepada Hyang Agung, dan takutlah kepada rasulnya. Bersungguhsungguhlah terhadap perintah ratu, Alloh, Muhammad dan pemimpin.

The text above stated that humans have to be obedient to the commandments of God and the Messenger. This is the marker of religious value, it is related to the teaching of religion especially Islam.

\section{- Honest}

Honest is the behavior that is based on the effort of making himself as someone who can always be trusted in the word, action, and employment, either against themselves or against others (Mustari, 2011: 11). In Serat Gembring Baring exemplified that humans should stay away from dishonest deeds, such as below.

// anom tuwå èstri priyå / gêdhé cilik sudagar miwah tani / sanadyan kang bångså luhur / yèn ngambah bobotohan / adu-adu rêrékan apus-pingapus / kurang gawé wong agêsang / dadyå kasukaning éblis // (SGB/Pang/p7/g1-7)

Tua-muda, pria-winata, besar-kecil, saudagar dan petani, walaupun datang dari bangsa yang luhur, jika sudah melakukan judi/ taruhan, mengadu (hewan), merekayasa, melakukan penipuan, akan menjadi manusia pemalas dan menjadi kesukaan iblis.

// ywå calimut lan åjå goroh ing ujar / lan malih toging urip /
(SGB/Dur/p71/g1-2)

Jangan suka mencuri dan berbohong dalam berbicara apa lagi sampai mati.

The text above explained that anyone who lies and gambling would be the preferred human demons. This is the one that marks the value of the character to be honest, the context of the text explained that human should be honest.

\section{- Dicipline}

Discipline is the act of proving conduct orderly and obedient at the various provisions and regulations (Mustari, 2011: 35), while dicipline according to Suyadi in Kemendiknas (2013:8) is the habits and actions that are consistent in all forms and rules of conduct in force. Thus, the character of the discipline is carried out by means of obedience or obedient and not be separated from the rules that apply. It is explained in the text of Serat Gembring Baring as below.

\section{/ rumêkså nalar mulyå / êndi liré ingkang anjidhari laku / angangsarakên cilåkå / ambubrah ing nalar bêcik // \\ (SGB/Pang/p6/g4-7) \\ Jagalah akal yang baik yang mana untuk membatasi perbuatan yang menyengsarakan, mencelakakan, dan merusak akal baik.}

The section above explained that human must always keep a sense of good thingking so they can keep far from the wretched and staying on the right path. This is dicipline in Serat Gembring Baring. By dicipline human will always be on the rigth path.

\section{- Hard Work}

Hard work is the behavior that shows an earnest effort in overcoming the various barriers to learning and assignments, doing a job as good as possible (Mustari, 2011:43). 
No one can live with prosperous without effort. This is exemplified in Serat Gembring Baring below.

// milané wong anèng donyå / rong prakårå dèn têmêni / olah sampurnaning pêjah / olah luhuring kamuktin /

(SGB/Sin/p16/g1-4)

Oleh karena itu manusia di dunia ini hendaknya belajar dua hal dengan sungguh-sungguh. Kedua hal itu adalah ilmu kesempurnaan mati (agama) dan ilmu kesempurnaan hidup (tingkah laku)

The above described that human must work hardly and seriously. If they want to get a happy life both in the world and in the hereafter, they should serious in work. They have to work hard if they want to reach something.

\section{- Democratic}

Democratic is a way of thinking, behaving and acting that assess the same rights and obligations themselves and others (Mustari, 2011:137). In a democracy, everyone has the same status without anyone differentiated. Here the example.

/ tan bédå èstri jalu / rèhning munggèng ing pråjå niti / sabêcikané kurang / bêcik ingkang punjul/among arjaning sarirå / (SGB/Dha/p4/g4-8)

Pria dan wanita itu tidaklah berbeda karena bagi Allah, sebaik-baiknya yang kurang itu lebih baik yang lebih dalam menjaga keselamatan raganya.

The text above explained that each human being both men and women have the same position in the eyes of God except their devotion and faith. This value marks the character of democracy, because it relates to justice where the status of everyone is the same.

\section{- Curiosity}

According to Kemendikbud in Suyadi (2013:9), curiosity is a way of thinking, attitudes and behaviour which reflect the curious and curiosity towards all things seen, heard, and studied in greater depth. This is in accordance with the opinion of Mustari (2011:85) stating that curiosity is the attitude and action is always striving to learn more in-depth and expanded from what he had learned, seen, and heard. The example of the character of the curiosity is exist in Serat Gembring Baring as below.

/ åjå lumuh ing sastrå Arab myang Jawi / sokur wignyå sêdåyå //

(SGB/Dha/p30/g9-10)

Jangan sampai sungkan untuk belajar Sastra Arab dan Sastra Jawa, syukur bisa pintar keduanya.

\footnotetext{
/tatakon têkironan / êndi kang amrih basuki /arjaning jasad / (SGB/Dur/p17/g4-6)

Bertanya-tanyalah mana yang membuat badan menjadi selamat.
}

Part of Serat Gembring Baring above explains not to hesitate or ashamed to ask and learn. Don't be to shy to ask and deepen a useful knowledge, this marks the character of curiosity in Serat Gembring Baring.

\section{- Respect}

Appreciating the achievements (respect) is the attitude and actions that push themselves to produce something useful for the community, recognize and respect the success of others (Mustari, 2011:121). The examples of that character is states below.

// rinaosnå kalawan pinikir / linakonå kang kalawan rilå / paugêraning krahayon / åjå angrusak urus / ngaras-aras myang ngiribbirib / manungså kang wus limpat / pintanên kang tuduh / (SGB/Dha/p11/g1-6)

Rasakan, pikirkan, dan lakukan dengan kerelaan itu cara mendapat keselamatan. Jangan merusak aturan dengan mencium 
serta menyamai perbuatan orang yang sudah mumpuni

The text above mentioned that humans should stay away from envious, do not jealous to the person who has a lot of knowledges. In other words we have to respect him. It became a marker of the character of respect.

\section{- Friendly/Communicative}

Friendly/communicative is an effort to connect to everyone. It is exemplified in the following section.

// utamané srawungan lan anglir / lan wong ingkang samyå ulah nalar / lan wong mangulah ngèlmuné / wus pasthi manggih untung / nora tunå sabarang budi / (SGB/Dha/p24/g1-5)

Keutamaan bergaul dan membaur dengan manusia yang menggunakan akal dan ilmunya sudah pasti mendapatkan keuntungan, tidak rugi akan hal baik.

The text above described that as a social creature, human should be to get along with each other, so relationships between each other are interwoven. That is the marker of friendly/communicative in Serat Gembring Baring. By interacting with others we will get a wide range of knowledge and information that other people have.

\section{- Social Care}

Social care is a mutual help, where help is the willingness of consciously and from the heart to give help to others in the form of words, deeds, or goods (Mustari, 2011:185). Social care can be done in a way to help others in the form of the action, advice, and so on. The value of the character of social care in Serat Gembring Baring exemplified in the section below.

/ milå sagunging jalmi / gêdhé cilik anom sêpuh / miwah pawèstri priyå / wajib gêgulang ngasami / dipunémut marang kang dadyå tulådhå//

(SGB/Sin/p23/g5-9)

Maka seluruh manusia, besar-kecil, tuamuda, pria-wanita, wajib mengajarkan (kebaikan) kepada sesama, agar mengingat yang sudah menjadi suri tauladan.

The section explained that a man should always to do good, both men and women, old and young. The good deeds can be anything, including giving advice to others to do good. It became a marker of the characters about social care.

\section{- Responsibility}

Responsibility is the attitude and behavior of a person to perform the duties and obligations, which they should do, towards theirself, society, environment (natural, social, and cultural), and God (Mustari, 2011:19). The character of responsibility in Serat Gembring Baring is exemplified in the following section.

/ amanat tyas pracåyå / amantêp tur wani mati / datan was uwas / nglabuhi tyas raharji /I

(SGB/Dur/p38/g4-7)

Amanat adalah percaya, mantap dan berani mati, tidak was-was, dan menjalani hati yang selamat.

From the section above it can be known that someone must be trusted. It is closely related to the character of the liability. This is in accordance with the character of responsibility, because according to the Ministry of education and culture of the Republic of Indonesia, one of the benefits of the character of the person in charge is being trusted and respected by the other (Kemendikbud, 2016:4).

\section{Discussion}

The contents of Serat Gembring Baring, states that to gain salvation, man must seek 
knowledge. It is still very relevant if linked in life at this time. It is also relevant to PP No. 47 year of 2008 regarding compulsory education. Compulsory education aims to provide a minimum education for citizens of Indonesia to be able to develop the potential for him to be able to live independently in the community or continuing education to a higher level, in order to have better life.

The necessity to look for knowledge both Java science and theology (Islam) is still very relevant to be done late this time. It is like in learning in schools, where in addition to being taught about science in general, also taught religious studies and also about lessons learned to behave. Therefore both knowledges are good to be learned in life at this time.

In addition to look for the knowledge, to reach the glory of life human must also do the virtues and steer clear of bad deeds. It is still very relevant to life today. In the life of a nation and a country has already made various rules set forth in the legislation in order to make each citizen doing the deed in accordance with the regulations-legislation. The regulation contains about recommending or restrictions.

In addition on how to reach the glory of living, the contents of Serat Gembring Baring can also be associated with character education. There are 10 character values in Serat Gembring Baring, namely: religious, honest, discipline, hard work, democratic, curiosity, respect, friendly/communicative, social care and responsibility. The character values in accordance with the program of Strengthening Character Education (Penguatan Pendidikan Karakter) from Ministry of Education and Culture of Republic of Indonesia that aims to help human beings become smarter and grow up to be a good people in order to prepare for the Golden Generation 2045 (Kemdikbud, 2018).

The value of the character in Serat Gembring Baring also complies with research of Kadek Herawan Dedy and I Ketut his Sudarshana (2017) entitled "The Relevance of Character Education in Sudhamala Geguritan to Improve the Quality of Indonesian Education". In that research the character value has relevance or affinity of competence that should be produced by graduate education in Indonesia.

Futhermore, the character values contained in Serat Gembring Baring also in line with the National Movement of Mental Revolution that proclaimed by the President of the Republic of Indonesia at the moment, Joko Widodo. That values very appropriate to the characters value that are required in National Movement of Mental Revolution.

\section{CONCLUSION}

There are 11 Serat Gembring Baring found from manuscripts inventory, however only one text that used for the research which is in Serat Pranacitra script, the library collection of Balai Bahasa Yogyakarta. The condition of the script and text is good and can be read clearly. The text of Serat Gembring Baring contains teachings so that humans can reach for the safety of life, both in the world and in the hereafter. In Serat Gembring Baring, there are 6 things that must be done to achieve the life safety, namely: (1) must have knowledge; (2) must learn about theology (Islam) and science of Java; (3) do the goodness; (4) stay away from the bad things; (5) always pray; and (6) have faith.

The content of Serat Gembring Baring also describes the characters value to human life. There are 10 characters value of Serat Gembring Baring which is still relevant 
to the current life, namely: religious, honest, discipline, hard work, democratic, curiosity, respect, friendly/communicative, social care and responsibility.

\section{ACKNOWLEDGEMENT}

This journal was made based on research conducted in the year of 2018 to fulfil the final exam of Java Education Departement, Graduate Program, Universitas Negeri Yogyakarta. Thanks to you who read, giving correction and suggestion to this article.

\section{REFERENCES}

Darusuprapta, dkk. (1985). Beberapa masalah kebahasan dalam penelitian naskah. Widyaparwa, Nomor 26. Yogyakarta: Balai Penelitian Bahasa Departemen P \& K.

Dhavamony, M. (1995). Fenomenologi agama. Yogyakarta: Kanisius.

Herawan, K.D. \& Sudarsana, I.K. (2017). Relevansi nilai pendidikan karakter dalam Geguritan Suddhamala untuk meningkatkan mutu pendidikan di Indonesia". Jurnal Penjaminan Mutu, 3(2), 223-236. DOI: http://dx.doi.org/10.25078/jpm.v3i2.203.

Kementerian Pendidikan dan Kebudayaan. (2016). Mengembangkan tanggung jawab pada anak. Direktorat Pembinaan Pendidikan Keluarga Direktorat Jenderal Pendidikan Anak Usia Dini dan Pendidikan Masyarakat.

Kementerian Pendidikan dan Kebudayaan. (2018). Penguatan pendidikan karakter. Diakses tanggal 7 Juni 2018, dari http://cerdasberkarakter.kemdikbud .go.id/?page_id=132.
Muhaimin. (2006). Pendidikan Islam: Mengurangi benang kusut dunia pendidikan. Jakarta: PT Raja Grafindo Persada.

Mustari, M. (2011). Nilai karakter refleksi untuk pendidikan karakter. Yogyakarta: Laksbang Pressindo.

Olivele, P. (2012). Material culture and philology: Semantic of mining in ancient India. Journal of the American Oriental Society, 132(1), 23-30. DOI: 10.7817/jameroriesoci.132.1.0023.

Poerwadarminta. W.J.S. (1939). Baoesastra Djawa. Groningen, Batavia: J.B Wolters' Uitgevers-Maatschappij N.V.

Presiden. (2008). Peraturan Pemerintah RI Nomor 47, Tahun 2008, tentang Wajib Belajar.

Suprayogo, I. (2001). Metodologi penelitian sosial-agama. Bandung: Remaja Rosda Karya.

Sudaryanto. (1993). Metode dan aneka teknik analisis bahasa: Pengantar penelitian wahana kebudayaan secara linguistis. Yogyakarta: Duta Wacana University Press.

Suyadi. (2013). Strategi pembelajaran pendidikan karakter. Bandung: PT Remaja Rosdyakarya. 